\title{
“Kadınlık” Deneyimi Kavramını Kadınların Gözünden Anlamlandırma Çabası: Göç Süreciyle İş Hayatına Giren Kadınların "Kadınlık” Deneyimlerine Dair Bir Sosyolojik Analiz
} An Interpretation of the Feminine Experience through the Eyes of Women: A Sociological Analysis of the Feminine Experience of Women Entering the Labor Force through Migration

Asiye Kemik*

Öz: Geçmişten günümüze kadar göç olgusu, nedenleri ve sonuçları itibarıyla pek çok farklı perspektiften ele alınmışır. Göç üzerine yapılan çalışmalar genel olarak incelendiğinde ise pek çoğunda toplumsal cinsiyet ile ilgili bir ayrıma gidilmediği dikkat çekmektedir. Dolayısıyla merkeze konulan erkeklerin deneyimleri, göç sürecini yaşayan diğer erkeklere ve kadınlara genellenmekte ve göç olgusu, cinsiyet kimliğinden bağımsız bir şekilde ele alınamamaktadır. Yine göç çalışmalarının çoğunda; cinsiyet, sosyoekonomik durum, kültürel özellikler, etnik ve dinî kimlik bağlamlarında, her bir bireyin göç sürecinden farklı etkilenebileceği de gözden kaçırılmaktadır. Bu gerçeklikten hareketle yapılmış olan bu çalışmada, kırdan kente yapılan iç göç hareketi; göç süreciyle iş hayatına giren kadınların 'kadınlık deneyimleri' bağlamında ele alınmıştır. Diğer yandan literatürdeki ‘deneyim’ kavramı, bazı kadınların deneyimlerini ön plana çıkarırken bazı kadınların deneyimlerini ikinci plana itmektedir. Dolayısıyla bilgi üretimi noktasında, çoğu zaman görünmeyen bir iktidar ilişkisi kurulmakta ve 'baskın' olan kadınlık deneyimleri diğer kadınlara genellenerek onların bilgisini üretmektedir. $\mathrm{Bu}$ gerçeklikten hareketle kavramın içi, alan araştırması süresince görüşme yapılan kadınların söylemleri dolayımıyla doldurulmuş ve ele alınan deneyim kavramı çalışmada, bilgi üretimi noktasında kullanılmıştır.Nitel araştırmanın benimsendiği bu çalışmada, 8 kadın ile derinlemesine görüşmeler yapılmıştır. Araştırma sonucunda ise görüşme yapılan kadınların geleneksel rol ve görevler bağlamında kadını tanımlayarak nesneleştirdiklerini ve nesneleştirdikleri 'kadın' tanımı çerçevesinde 'kadınlık deneyiminin' içini doldurduklarını söylemek mümkündür. Dolayısıyla bu durum bizi deneyimin de nesneleştiği/şeyleştiği gerçeği ile karşı karşıya getirmektedir.

Anahtar Kelimeler: İç Göç, Deneyim, Kadınlık Deneyimi, Nesneleşen/Şeyleşen Kadınlık Deneyimi

Abstract: There have been multiple perspectives on the phenomenon of migration from the past until the present. When migration studies in general are analyzed, it is observed that most of them do not take gender

\footnotetext{
* Doktora Öğrencisi, Sosyoloji Bölümü, Muğla Sttkı Koçman Üniversitesi, asikemik@ gmail.com, ORCID: 00000002-0745-4350
} 
into consideration and male experiences placed in the center are generalized to the other men and women who have migration experiences, as well. As a consequence, the phenomenon of migration is discussed without a gender lens.; It is overlooked by many migration studies that each individual may be affected differently from migration processes in terms of one's gender, socio-economic status, cultural characteristics, ethnic and religious identity. Based on this reality, this study discusses internal migration movement from rural to urban areas in the context of the feminine experience of women who enter the labor force through migration. The concept of experience emphasizes some women's experiences at the cost of making the rest as secondary, which establishes a relationship of power. The rest is often invisible in the knowledge production processes as the former's experiences dominate the field. In this study, discourses on the concept of experience are used for knowledge production. In this qualitative study, in-depth interviews were conducted with 8 women. As a result of the research, it can be stated that participants have defined and objectified women in the context of traditional roles and tasks and they constructed feminine experience via those definitions. Therefore, this situation leads to the fact that experience is also objectified.

Keywords: Internal Migration, Experience, Femininity Experience, Objectifying Femininity Experience

\section{Giriş}

Göç analizi yapılırken göçün toplumsal bir süreç olmasının yanı sıra bireysel bir süreç olduğu da göz önünde bulundurulmalı ve göç olgusunun kendisi üzerinde odaklanılırken göç eden bireyler birer aktör olarak ihmal edilmemelidir. Göç eden bireyler ise homojen bir yapıda ele alınmamalıdır. Çünkü "mevcut çalışmalar göç nedenleri, göç sürecine katılım, bu süreç esnasındaki yaşam deneyimleri ve göçün etkileri, göç edenlerin tutumları ve tepkileri açısından kadınlar ve erkekler arasında önemli farklılıklar olduğuna işaret etmektedir. $\mathrm{Bu}$ farklılıkların temelinde kadın-erkek arasındaki aile içi iş bölümü ve buna paralel olarak gelenekler ve görenekler tarafından tanımlanan toplumsal kadın-erkek rolleri yatmaktadır. Kadınların göçe ilişkin yaşantıları genellikle, bir eş, anne ya da evlenmek üzere olan genç kız olarak aile içindeki konumları ile yakından ilişkilidir. Gerek ayrıldıkları gerekse göçle geldikleri yeni mekânla olan ilişkileri de bu temelde belirlen[mektedir]" (İlkkaracan ve İlkkaracan, 1999: 305). Bu bağlamda göç ile ilgili yapılan çalışmaların pek çoğunda erkek egemen bir bakış açısının hâkim olduğu ve kadınların ikinci planda kaldıkları dikkat çekmektedir. Dolayısıyla -nesneleşen/şeyleşen deneyim kavramı bağlamında- kırdan kente göç ile birlikte ücretli işgücüne katılan kadınların 'kadınlık' deneyimlerinin ele alındığı bu çalışmanın amacı; kaynak bölgede geleneksel aile işçisi olarak çalışan kadınların, hedef bölgede "ücretli iş gücüne katılmalarıyla” birlikte gündelik yaşamlarında ne gibi deneyim değişiklikleri ile karşılaştıklarını analiz edip anlamaya çalışmaktır.

Göçün araç olarak kullanıldığı bu çalışmada, deneyim kavramının içi ise alan araştırması süresince görüşme yapılan kadınların söylemleri dolayımıyla doldurulmuştur. Görüşme yapılan 
kadınların kendilerini ve birbirlerini nasıl algıladıkları üzerinden dile getirmiş oldukları deneyimler, -deneyimi yaşayan kişilerin bakış açılarının deneyimi biçimlendirmekte olduğu gerçeğinden hareketle- içinde bulunmuş olduğumuz ataerkil toplumu ve bu toplumun bireyler üzerinde dayatmış olduğu eril tahakkümü dışarıda bırakmamak adına "salt bilgi” olarak değil eleştirel bağlamda hermeneutik bir anlama çabası ile ele alınmıştır. Ayrıca kültürel faktörlerin bireylerin davranış ve söylemleri üzerindeki etkilerini görmezden gelmemek adına; alan araştırmasında elde edilen bulgular, kültürel faktörlerin önemi üzerinde özellikle duran postmodern feminist anlayışın bu anlamdaki görüşleri de dikkate alınarak yorumlanmaya çalışılmıştır. Çünkü deneyimi; bireylerin bakış açılarını etkileyen toplumsal bağlantıları analiz etmeden bilgi üretimi noktasında kullanmak demek, içinde bulunulan toplumun birey üzerindeki etkilerini göz ardı etmek demektir.

\section{Literatürde Yer Alan İç Göç Kavramı ve Kadın Olgusu Üzerine}

Tek bir tanımı mevcut olmayan çok boyutlu, karmaşık ve heterojen bir olgu olan göç olgusu; geçmişten günümüze kadar nedenleri ve sonuçları bağlamında farklı perspektiflerden ele alınarak tanımlanmıştır. Herhangi bir tanımı ötekine öncelemek eksik bir bakış açısını beraberinde getirecektir. Zira her biri göçün farklı boyutuna değinen bir tanımı, diğerinden ayrı düşünmek neredeyse imkânsızdır. Bu bağlamda göç olgusunu, göç etme nedenleri noktasında zorunlu ve gönüllü göçler diye sınıflandırırken göç hareketinin yurt içi ve yurt dışı olması bağlamında iç göç ve dış göç olarak sınıflandırmak mümkündür.

Geniş anlamıyla “insan hareketliliği” şeklinde tanımlamanın mümkün olduğu göç olgusu, yalnızca fiziki bir yer değiştirmeyi değil aynı zamanda sosyo-ekonomik ve kültürel bir yapıdan diğerine geçmeyi de ifade etmektedir (Şeker ve Uçan, 2016: 198). İç göç kavramı ise belli bir ülke içinde; bölge, kent, kasaba ve köy gibi yerleşim yerlerinin birinden diğerine yerleşmek amaciyla yapılan bir hareket şeklinde tanımlanmaktadır (Keleş, 1998: 40-63).

Türkiye bağlamında; 1923-1950 dönemi, 1950-1960 dönemi, 1960-1980 dönemi ve 1980 sonrası şeklinde dönemlere ayrılan iç göç olgusunun özellikle 1950'li yıllarda toplumu derinden etkileyen bir olgu olarak ortaya çıktığını söylemek mümkündür. İç göç ile ilgili literatür incelendiği zaman iç göç olgusunun; göçe neden olan sosyo-ekonomik, kültürel, güvenlik vb. etmenler bağlamında ele alınarak kırın itici etmenleri ile kentin çekici etmenleri üzerinde durulduğu dikkat çekmektedir (Başel, 2006; Coşkun, 2008; Gündüz ve Yetim, 1996; Gür ve Ural, 2004; Oktik, 1996). Bazı çalışmalarda ise yalnızca niceliksel olarak kadınlara yer verilmekte, kadınların göç etme oranlarının erkeklerden daha az olduğu üzerinde durulmaktadır (Coşkun 2008; Kocaman, 2008). Ancak bu duruma neden olan toplumsal cinsiyet temelli etmenler üzerinde duran 
çalışmalara rastlanılamamaktadır. Kadınların göçe dâhil olmalarını, yalnızca bağlantılı göç üzerinden ele alan bazı çalışmalarda ise göç etme sürecindeki kadınlar, aile bireylerinden herhangi bir erkek üyeyi (baba, eş, erkek kardeş vb.) takip eden pasif bireyler olarak resmedilmektedir. Ancak "birey" olarak kendilerine ait itme-çekme nedenleri yüzünden göç eden kadınların varlı̆̆ da söz konusudur.

İç göçün sonuçları bağlamında literatür incelendiği zaman ise sonuçların genellikle kentleşme, kentlileşme, gecekondulaşma, yoksulluk ve istihdam gibi alt başlıklar altında ele alındığı ve yine pek çok çalışmada toplumsal cinsiyet eksenli bir ayrıma gidilmediği dikkat çekmektedir (İçduygu, Sirkeci ve Aydıngün, 1998; Kaya, 2007). Hâlbuki kadınlar göçe, toplumsal cinsiyet rolleri gereği üstlenmiş oldukları sorumluluklarla katıldıklarından dolayı hem göç sürecinin hem kadın olmanın mağduriyetini birlikte yaşamaktadırlar (Sam'dan akt. Şeker ve Uçan, 2016: 206).

Her ne kadar "kır-kent göçünde esas hareket edenin erkek olduğu varsayılmış olsa da hem kadınlar bu sürecin bir parçasıdır hem de göçün ve göç ettikleri kentlerde gelişmelerin esas aktörleridir" (Kaypak, 2014: 351). Dolayısıyla hem göçe katılma süreçleri hem de bu süreçten etkilenmeleri anlamında, kadın ile erkek arasında toplumsal cinsiyet eksenli bir ayrıma gidilmeli; süreci yaşayan erkeklerin deneyimleri, süreci yaşayan kadınlara genellenmemeli; hatta kadınlar da kendi içlerinde homojenleştirilmemelidir.

Göç sürecinde kadının, erkekten ayrı ve kendine özgü bir biçimde ele alınıp incelenmesi gerektiği fikri ilk olarak uluslararası kadın konulu konferanslarda (Birleşmiş Milletler Kadınlar Üzerine Dünya Konferansı, 1975, Meksika; Kadınların On Yılı Üzerine Dünya Konferansı, Kopenhag, 1980) dile getirilmiştir. Erken dönem feminist göç çalışmalarında kadınların; göç etmiş oldukları ülke ekonomisine katkıları ve onlara yönelmiş olan cinsel şiddet bağlamında ele alınarak göç sürecinin mağduru olan edilgen bireyler şeklinde temsil edildikleri dikkat çekmektedir. Bu dönem çalışmalarında kadınlar; geleneksel değerlerin taşıyıcısı ve koruyucusu olmaları vasfiyla kültürel uyum sürecini geciktiren stereotiplere dönüştürülerek yarattıkları sorunlar çerçevesinde ele alınmışlardır. Ayrıca kadınlar; özel alana hapsolmuş, kamusal yaşamda ise ezilen, erkeğin tahakkümü altında yaşamak zorunda kalan nesneler hâline dönüşmüşlerdir. Özellikle 1990'l1 yıllardan itibaren ise kadının, göç sürecinin "mağduru” şeklinde kodlanan pasif konumundan “değişimin faili” olarak tanımlandığı aktör konumuna doğru kaydığı dikkat çekmektedir (Şeker ve Uçan, 2016: 205).

$\mathrm{Bu}$ dönemden itibaren Türkiye'deki iç göç literatüründe kadınların iç göçe ilişkin deneyimleri; 1980’li yıllardan başlayarak daha çok 1990’lı yıllarda yapılan "kırdan kente göç” 
araştırmalarında "aile”, "iş gücü” ya da "sağlık" kapsamında ele alınmaya balanmıştır (İlkkaracan ve İlkkaracan,1998: 1). Yapılan pek çok çalışmada ise kadına göçün nedenleri ve sonuçları (kentleşme, kentlileşme, gecekondulaşma, istihdam vd.) bağlamında özellikle yer verilmeye başlanmıştır (Abadan Unat, 1991; Buz, 2009; Erman, 1998; İlkkaracan ve İlkkaracan, 1999; Onat, 1993).

Bu çalışmada ise kırdan kente iç göçün sonuçları; göç süreciyle ücretli iş gücüne katılan kadınların değişen/değişmeyen deneyimleri noktasında ele alınmaya çalışılmıştır. Bu bağlamda göç, isdihdam ve kadın ilişkisine öncelikli olarak değinmek gerekirse göç; istihdamı iki yönlü etkilemektedir: İlki; kırsal alandaki iş gücünün kentsel bölgelere taşınması ve kentteki işsizler arasında yedek iş gücü deposunun oluşması șeklindedir. Bu durum ücretlerin düşmesine ve kayıt dışılığın artmasına sebep olmaktadır. Dolayısıyla iş gücü piyasasının çalışma koşulları, iç göçün sonuçlarından olumsuz bir biçimde etkilenmektedir. İkincisi ise iş gücü yapısında meydana gelen dönüşümlerin toplumsal etkisidir. Çünkü tarımsal iş gücünden kentsel iş gücü yapısına geçişten, genellikle tüm hane halkı etkilenmektedir. Bu etkiler ise aile bireyleri (çocuk, kadın, erkek) üzerinde farklı şekillerde meydana gelir (Başel, 2006: 308-309). Örneğin kırda ücretsiz aile işçisi olan pek çok kadın, kente geldikten sonra ücretli iş gücüne katılabilmektedir.. Zira göçmen ailelerin yaşamış olduğu ekonomik sıkıntılar, -kentteki kadına kıyasla daha az beşerî sermayeye sahip olan- kırdan gelen kadınları düşük ücretli, güvencesiz ve vasıfsız işlere doğru yöneltmektedir (Korkmaz ve Korkut, 2012: 56). Başka bir deyişle; “'[k]adın emeği, 'ucuz' emek oluşu nedeniyle tekstil, hazır giyim, gıda ve tütün gibi emek yoğun sanayi dallarında tercih edilmekte ama bu aynı zamanda kadınların düşük ücretle çalışmalarına da neden olmaktadır. Özellikle imalat sanayinde, istihdam yaratma maliyetinin yüksek olması, bu alt dalın çok yavaş büyümesine ve kadın emeğinin ikincil konuma düşmesine neden olmaktadır" (Metin, 2011: 63).

Göçmen erkeklere ve yerleşik kadınlara göre daha vasıfsız işlerde istihdam edilen göçmen kadınların, aynı zamanda geleneksel "kadınlık" görevlerini de yerine getiriyor olduğu varsayımından hareket edilirse bu noktada kadınların aile içi sorumluluklarının arttığı söylenebilmektedir. Öte yandan kadın istihdamı; her ne kadar emek sömürüsü ekseninde temellense de aile bütçesine kadın tarafından destek sağlanması ve kadının özel alandan çıkarak kamusal alana dâhil olması bağlamında bazı yapısal değişim ve dönüşümleri de beraberinde getirebilmektedir. Kırda geleneksel olarak kadına ait olan ev işlerinin, kente göç ettikten sonra çalışma yaşamına katılan kadınların sahip olduğu ailelerde eşler arasında paylaşılması (Onat, 1993: 23); kadının aile içinde daha fazla söz sahibi olması ve ataerkil pratiklerde bazı dönüşümlerin meydana gelmesi gibi sonuçlar, bu duruma örnek olarak verilebilir (Buz, 2009: 47). Dolayısıyla göç sonrasında iş hayatına giren kadınlara yalnızca; emekleri sömürülen, hem kamusal 
alanda çalışıp hem de geleneksel "kadınlık" görevlerini yerine getiren ve kent yaşamına uyumları beklenen bireyler olarak bakılmamalıdır (Buz, 2009: 47). Zira göç etme ve göç etmeye karar verme sürecinde -genellikle- uyumları beklenen "pasif” bireyler olarak konumlandırılan kadınlar; göç ettikten sonra -iş hayatına giren kadınlar bağlamında- değişen "deneyimleri” söz konusu olduğunda "aktif” bireyler olarak "yeniden var olma” süreçlerini yaşayabilmektedirler. Bu "var olma" sürecinde, kadınların iş hayatına girmesiyle gündelik hayatlarında ne gibi deneyim değişikleri olduğu/olmadığı; göçün kadınlar açısından nasıl bir süreç olduğunun anlaşılıp yorumlanabilmesini kolaylaştıracaktır. Dolayısıyla göç çalışmalarında, kadınlık deneyimlerinin özellikle de bilgi üretimi noktasındaki önemi göz ardı edilmemelidir.

\section{2.“Kadınlık Deneyimi” Kavramının Bilgi Üretimi Noktasında Kullanılması}

Kadınlık deneyimlerinin önemsenmesi, kadınların bilgi alanındaki ikincileştirilmelerine karşı epistemolojik bir tavrı bünyesinde barındırdığı için "deneyim” kavramı feminist politikada önemli bir bilgi kaynağı olarak görülmektedir (Bora, 2005: 32). Ancak deneyimin "bilgi” olarak ele alınması noktasında, pek çok farklı bakış açısı bulunmaktadır. Örneğin; Sandra Harding, Donna Haraway, Alison Jaggar ve Dorothy Smith gibi bazı feminist duruş noktası kuramcıları; kadınların somut/gündelik deneyimlerini, sosyal bilim araştırmalarında başlangıç noktası olarak almayı önermektedirler. Bu araştırmacılar, deneyimlerin yalnızca soruların ortaya konulması için önemli olduklarını, cevapları sağlamak bakımından ise herhangi bir önemleri olmadığını ifade etmektedirler. Duruş noktası kuramcılarının bazılarına göre ise farklı grupların deneyimlerini görünür kılmak, baskı mekanizmalarını gösterirken bu mekanizmaların iç işleyişini ve mantığını ortaya koyamamaktadır. Dolayısıyla farklılıkların var olduğunu bilir ama bu farklılıkların nasıl inşa edildikleri noktasında yorum yapamayız. Bu bağlamda deneyim nosyonu ile belli bir sosyal konuma epistemolojik bir ayrıcalık tanınmamaktadır. Dolayısıyla söylem dolayımıyla özneleri konumlandırarak deneyimleri üreten/biçimlendiren tarihsel süreçler göz önünde bulundurulmalıdır. Görüldüğü üzere feminist duruş noktası kuramcıları arasında, kadınların deneyimlerine epistemolojik bir ayrıcalık tanıyan feminist amprizmden ve öznenin toplumsal konumlanışını temel alan yaklaşımlara kadar bir dizi farklılıklar ve tartışmalar bulunmaktadır (Öztan, 2016: 271-280).

İlk dönem feminist hareketten bu yana feminist kuramda ve politikada bilgi kaynağı olarak görülen deneyim kavramının nasıl ele alındığına kısaca değinmek gerekirse; Öncelikli olarak 1970’lerde kadınlar ve erkeklerin farklılıkları üzerine yoğunlaşan feminist kuram ve politikada deneyim kavramı uzun bir süre sadece batılı, orta sınıfa ait beyaz kadınların deneyimleri üzerinden kuramsallaştırılmıştır. Dolayısıyla Batılı feminist yaklaşımla üretilen politikalarda kendi 
'gerçekliğini' göremeyen üçüncü dünyalı feministler ve postmodernist feminist kuramcılar bu duruma tepki göstererek feminist politikalara yeni bir boyut kazandırmaya başlamışlardır (Tümen Bilgen, 2005: 1). Özellikle 1980'lere gelindiğinde ise feminist ilgi kadın ve erkek arasındaki farklılıktan ziyade kadınların kendileri arasında var olan farklılıklara yoğunlaşmıştır. Dolayısıyla Batıl1, beyaz ve orta sınıftan olan kadınların deneyimlerini yansıtan ve kadınların kendileri arasındaki farklılıkları görmezden gelen feminist bakış açısı eleştirilmiştir.

'Moderinist' ve 'pozitivist' düşünce yapısının küresel iddialarının yerini bölgesel niteliği olan yerel tartışmalar almaya başlamıştır. Bu noktada yerellik, bilgi üretimi noktasında ele alınacak olan deneyim kavramı bağlamında, önem arz etmektedir. Zira kadınlık deneyimi bağlamında global ölçekli yapılan bazı tanımlamalar; bazı kadınların deneyimlerinin genellenerek diğer kadınların deneyimlerinin bilgisinin üretilmesine ve görünmeyen bir iktidar ilişkisinin ortaya çıkmasına neden olmaktadır. Dolayısıyla deneyim kavramı bilgi üretimi noktasında kullanılırken dikkat edilmesi gereken bazı etmenler söz konusudur.

İlk olarak deneyimin nasıl ele alınacağı sorunsalı karşımıza çıkmadır. Zira deneyim, yaşanılan herhangi bir şeyi önceden sahip olunan değerler bağlamında değerlendirmek demektir. Bu noktada deneyimi yaşayan kişinin bakış açısı, bilgiyi biçimlendirmekte ve deneyim kavramının dolaysızca bilinmesi imkansız hale gelmektedir. Dolayısıyla deneyim kavramı dolaysız bilgi kaynağı olarak değil toplumsal gerçekliğin belirli bir kısmı olarak ele alınmalı ve deneyimin ifade edildiği toplumsal bağlantılar göz önünde bulundurulmalıdır (Bora, 2005: 33). Çünkü egemen ideolojiden azade olmayan, gündelik yaşam içinde yer alan bireyler, belirli bir konumlanmaya sahip olan öznelerdir aslında ve bulunmuş oldukları konumların onlara 'sağlamış' olduğu bakış açısı çerçevesinde deneyimlerini aktarmaktadırlar. Dolayısıyla "bütün deneyimler pratik, söylem ve yorumlama sürecinden geçer. Hiçbirimiz saf bir deneyime sahip değilizdir. Deneyim aynı zamanda bir yorum ve yorumlama ihtiyacıdır” (Skeggs 1997: 28 akt. Öztan, 2016: 280).

'Kendilik deneyimi’ denilen şeylerin söylemsel pratikler üzerinden yapılandırıldığını düşünen Joan Scott (1991; akt. Tümen Bilgen, 2005)'a göre deneyim kavramı, kadınlara yönelik baskıyı doğallaştıran ve kadınları baskılayan ideolojik sistemleri meşrulaştıran bir araca dönüşerek 'geçerli' söylemin temelini oluşturabilir. Aynı zamanda “deneyim üzerinden yapılanan 'gerçekliği' aydınlatma projeleri farklılığın veya baskının olduğunu gösterebilirken aynı zamanda ideolojik sistemin kendisinin nasıl çalıștığına yönelik bir incelemenin önünü de kesebilir” (Scott,1991: 778; akt. Tümen Bilgen, 2005: 6-7). Bu bağlamda riskli bir kavram olan deneyim üzerinden elde edilen, varsayılan şey, söylem öncesi bir gerçekliğe meşruiyet kazandırabilir. 
Tüm bunlar göz önünde bulundurulduğu zaman deneyim ile deneyimin temsil edilişlerinin birbirine eşitlenmeden ele alınmasına özen gösterilmelidir. Bu noktada ise post feminist anlayış ile hermeneutik anlama çabası, deneyimlenen şeyin içinde bulunulan sistemi dışarıda bırakmayan eleştirel bir yaklaşımla ele alınması noktasında önem arz etmektedir. Kısaca post- modern feminist anlayış ve hermeneutik anlama çabasına değinmek faydalı olacaktır.

\section{Post-modern feminist anlayış}

Post-modern feminist anlayış pozitivist anlayışın değerden arınmışlık ilkesini eleştirerek pozitivist ve modernist anlayışın cinsiyeti kadın ve erkek olarak kategorileştirirken kendi aralarında herhangi bir ayrım gözetmeyen homojenleştirici bakış açısına karşı çıkmaktadır. Dolayısıyla genelleştirilmiş söylemlere karşı çıkan postmodern feminist hareket, farklı anlayışlar içinde kadınların savunusunun yapılması gerektiğini ileri sürmektedir. Bu bağlamda ırk, sınıf, cinsiyet, etnik köken gibi farklılıklar postmodern feminist yaklaşımı içinde değerlendirilmektedir. Kadınlara ait evrensel doğruların olmadığını, etnik, yerel, kültürel farklılıkların da dikkate alınması gerektiğini savunan post-modern feminizme göre içinde bulunduğumuz çağda kadınların tek tip sorunu yoktur (Yüksel, 2001:111). Zira evrensel bir kadın kategorisinden bahsedilmesi ve bu bağlamda deneyimin de evrensel olarak kabul edilmesi kadınlar arasındaki sosyo- ekonomik ve kültürel farklılıkları görünmez kılacaktır. Kadınların kültürle ilişkisini anlamada ise, dil çok önemli bir unsur olarak karşımıza çıkmaktadır. Zira ataerkilliğin dili kadını bir ötekilik içinde kurgulamakta ve kadınlığın tarifini de kendi erkekliği üzerinden yapmaktadır. Böylelikle kadınları kendi dilinden nesneleştirerek kendi özneliğinin kuruluşunun aracısı yapmaktadır (Taş, 2008: 12). Kadınların var oluşunu mahremiyet, sessizlik, gibi kavramlarla tanımlayan ataerkil ideolojilerin hakim olduğu toplumlarda kadınlar dil ötesi bir alana hapsedilmektedir (Irzık ve Parla, 2004: 7). Erkekler tarafından üretilmiş bir dilin içinde yaşayarak ötekileştirilen kadın ise kendisini tam anlamıyla ifade edememektedir. Kadının bu ötekilikten kurtuluşu için kendi dilini oluşturması gerektiğini düşünen Luce Irigaray, Julia Kristeva ve Helene Cixous gibi bazı teorisyenler dişil dil üzerine bazı teoriler ortaya koymuşlardır

Örneğin; Irigaray 'kadın gibi' konuşmak ile 'kadın olarak' konuşmak arasında keskin bir ayrım olduğunu dile getirir. Erkek gibi konuşmak ve yazmanın yetenekli olmanın göstergesi olduğu eril toplumlarda kadın gibi konuşmak bir yeteneğin olumsuzlanmasına eşdeğer olarak görülmektedir. 'Kadın olarak' konuşmak ise psikolojik bir konumlanmanın yanı sıra toplumsal bir konumlanmaya da işaret etmektedir (Taş, 2008: 28- 29). İkili karşıtlıkların temelinde erkek/kadın ikiliğinin bulunduğunu dile getiren Cixous ise kadınların susturulmasına neden olan bu kültür 
sistemini yıkacak dişil bir dil arayışındadır. Zira bir kültürün erkek egemen baskınlığının göstergelerinden biri eril dil yapısının kendisidir (Taş, 2008: 16).

Bu bağlamda kültürün şekillenmesi ve aktarılmasında dilin önemi yadsınamaz bir gerçeklik olduğundan hareketle bu çalışma boyunca kadınlık deneyimleri, hermeneutik anlama çabası merkeze konularak ele alınmaya çalışılmıştır.

\section{Hermeneutik Anlayış}

"Etimolojik olarak Grek mitolojisinde yazının, dilin mucidi olarak tanrısal mesajları

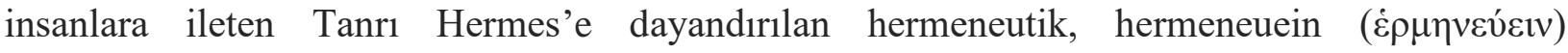

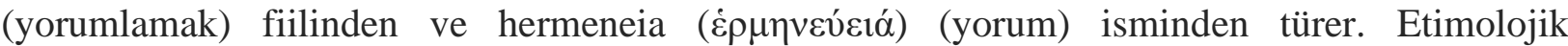
kökeninden de anlaşılabileceği gibi kavram, ifade etme, söyleme, haber verme, çeviri yapma, anlama, açıklama ve yorumlama anlamlarını içerse de bu anlamlar içinde en kökensel olanı yorumlama etkinliğinin zeminini oluşturan 'ifade etme'dir" (Aşkın ve Çellik, 2015:2). Anlamı anlamaya yönelik, felsefi ve bilimsel bir etkinlik olan hermeneutik bir yorumlamadır. Bu yorumlama salt nesnelerin görüntülerinden ve kendi kendilerini anlatmalarından ibaret değildir. Kendine özgü sınırı ve bilme biçimi olan hermeneutiğin bu anlamda ontolojik ve epistomolojik bir temeli vardır (Taşdelen, 2008: 13-16).

Hermeneutik anlayış dünya hakkında belli bir görüşe sahip olan insanın bilinçli olarak dünyaya belli bir açıdan bakmakta olduğunu kabul eder. 'Sosyal aktörün ne olduğu' ve 'araştırmacının insan ve toplumu nasıl araştırması gerektiği' sorusunu cevaplamayı amaçlayan hermeneutik yöntem bu anlamda olayların iç gözlemle içerden araştırması gerektiği öngörmektedir (Kuyucuoğlu, 2015: 682).

İnsanın kazanımlarının yalnızca duyusal deneyimlerle değil, bütün beşeri tecrübelerle oluşmakta oluştuğunu düşünen Dilthey'e göre; evren bağımsız olgularla değil, kendi içinde yapısal bütünlük arz eden deneyimlerle anlam kazanmaktadır. Hayatın, içsel olarak yaşanan ve yorumlanması gereken beșeri bir deneyim olduğunu düşünen Dilthey, düşüncenin hayatın ötesine geçemeyeceğini, hayatın kategorilerinin 'aşkın gerçeklikte' değil, bilfiil 'yaşanan deneyim' gerçekliğinde aranması gerektiğini ifade etmektedir (Palmer, 2008; akt. Kuyucuoğlu, 2015: 683684).

$\mathrm{Bu}$ bağlamda "Weber'e göre bilgi ancak bireylerin öznel deneyimlerini anlayıp yorumlamak ile kazanılabilir. İnsanın evren oluşturma sürecini kavramak isteyen bu paradigmanın amacı sosyal aktörlerin perspektifinden evreni anlamaktır. Zira toplumsal gerçeklik tamamen önceden var olan olgusal bir yapı değil, meydana getirilen bir süreç veya bir olgudur. Kendimizi ve çevremizi tanımayı sağlayan, deneyimlerimizin uzantısı olan bilinç, hermeneutikçi sosyal bilim 
yöntemlerinin merkezinde yer almaktadır” (Kuyucuoğlu, 2015: 685). Dolayısıyla deneyim kavramı ile deneyimin söylem olarak ifade edilişi birbirine eşitlenmemelidir. Zira Habermas'a göre söze dökülmüş olan şeyler hiçbir zaman basit birer söz dizini değillerdir. Çünkü söylemin anlamı, özneler arası içerikten türemektedir. Bu noktada dil ise içinde bulunulan sosyal dünya ve bu sosyal dünyanın kültürel faktörleri tarafından kuşatılmış durumdadır (Çelik ve Ekşi, 2008: 101102). Bu durumu Clifford Geertz (1973: 5; akt: Kuyucuoğlu 2015: 682) “İnsan, kendi ördüğï belirlilik ağlarında asılı bir canlıdır. Kültürü bu ağlar olarak ele alıyorum, bundan dolayı da onu analizinin kurallarının araştırıldığı "deneysel" bir bilim olarak değil, anlamın araştırıldığ “yorumsamacı" bir alan olarak düşünüyorum" sözleriyle ifade etmektedir.

\section{Araştırmanın Yöntemi ve Alanına Dair}

Göçün araç olarak, deneyim kavramının ise bilgi üretimi noktasında kullanıldığı bu çalışmada 'deneyim' kavramının içi, alan araştırmasında görüşülen kadınların söylemleri bağlamında doldurulmuştur.

Amacı; kadınlık deneyimlerini ölçmek değil anlamak ve yorumlamak olan bu çalışmada, alan verileri derinlemesine mülakat tekniği aracılığıyla toplanmıştır. Toplanan veriler, hermeneutik anlama çabasıyla ele alınarak değerlendirilmiştir. Ayrıca deneyimin şekillenmesi noktasında kültürel etmenlerin üzerinde durarak bireylerin homojenleştirilmesine karşı çıkan postmodern feminist anlayışın bakış açısı da göz önünde bulundurulmuştur. (Kadınlık deneyiminin bilgi üretimi noktasında kullanılması adlı bölümde ayrıntılı olarak değinilmiştir.)

Bu çalışmanın alan araştırması kısmı, Antalya'nın Manavgat ilçesinin Çolaklı beldesinde bulunan Gedikliler Mahallesi olarak bilinen Merkez Mahallesinde gerçekleştirilmiştir.

Yaklaşık on iki hanenin bulunduğu Merkez (Gedikliler) mahallesinde yaşayan insanların pek çoğu Isparta'nın Şarkikaraağaç ilçesinin Gedikli köyünden iç göç ile gelmişlerdir. Gedikli köyündeyken geçim kaynakları genellikle hayvancılık, balıkçılık, kesimcilik, kiraz ve vişne ağırlıklı olmak üzere meyve yetiştiriciliği olan bireyler turizmin sağlamış olduğu istihdam olanağından dolayı Çolaklı’ya gelerek -pek çoğu- turizm sektöründe çalışmaya başlamıştır.

Merkez (Gedikliler) mahallesinin alan araştırması için tercih edilme nedeni, kaynak bölgede ücretsiz aile işçisi olarak çalışan kadınların pek çoğunun, hedef bölgede ücretli işgücüne katılmış olmalarıdır.

Görüşme yapılacak olan bireyler belirlenirken ise; değişen deneyim söz konusu olduğu zaman; göçün kadınlar açısından nasıl bir süreç olduğunu anlayıp yorumlayabilmek adına, kırdan 
kente göç ile birlikte işgücüne katılan ve süreci anlatabilecek olan kadınlar tercih edilmiştir. Görüşme yapılacak olan kadınlara ortak tanıdıklar aracılığı ile ulaşılmıştır.

Hermeneuitik anlama çabasıyla ele almaya çalıştığım alan verilerini analiz ederken, özellikle kendi deneyimlerim üzerinde düşünme fırsatım oldu. Özellikle alan verilerini deşifre ederken içerden gelen “Asiye çay demlenmiş mi?” diyen annemin sesinin bunda payı büyüktür. Çayı ocağa koyanın her akşam kendisinin olması ve odada erkek kardeşim olduğu halde çaya bakacak olanın ben olmam...

Hem toplumsal rol ve kalıplarla çevresi donatılmış olan bir kadın hem de bu kalıpların dışına çıkmaya çalışarak alana bakmak isteyen bir araştırmacıydım. Bu nedenle kadınların söylemlerini anlamlandırma çabası süresince kaleme aldığım her cümlenin sonunda "bunu bana yazdıran toplumsal rol ve kalıplar nelerdir?” sorusunu kendime yöneltmeye çalıştım.

\section{Alana Verilerinin Analizi ${ }^{1}$}

Araştırmanın kolay incelenmesini sağlamak ve araştırmacıya yol göstermek amacıyla aşağıdaki tabloda görüşme yapılan bireylerin temel referansları belirtilmiştir.

\subsection{Demografik Analiz}

Tablo 1: Görüşme Yapılan Bireylerin Temel Referansları

\begin{tabular}{lllllll}
\hline Yaş & $\begin{array}{l}\text { Medeni } \\
\text { Durum }\end{array}$ & $\begin{array}{l}\text { Kaç } \\
\text { Yıldır } \\
\text { Evli }\end{array}$ & $\begin{array}{l}\text { Çocuk } \\
\text { Sayısı }\end{array}$ & $\begin{array}{l}\text { Çolaklı'da } \\
\text { yaşama } \\
\text { süresi }\end{array}$ & İş-Meslek \\
\hline G1 & 35 & Evli & 15 & 1 & 8 & Turizm sektöründe çalıştı. \\
\hline G2 & 43 & Evli & 19 & 2 & 16 & Turizm sektöründe çalışmaktadır/Esnaf \\
\hline G3 & 49 & Evli & 29 & 2 & 29 & Turizm sektöründe çalışmaktadır/Esnaf \\
\hline G4 & 42 & Evli & 18 & 2 & 14 & Turizm sektöründe çalışmaktadır. \\
\hline G5 & 32 & Evli & 12 & 2 & 13 & Turizm sektöründe çalışmaktadır. \\
\hline G6 & 41 & Evli & 9 & 2 & 16 & Turizm sektöründe çalışmaktadır \\
\hline G7 & 30 & Evli & 10 & 1 & 11 & Turizm sektöründe çalışmaktadır. \\
\hline G8 & 44 & Evli & 25 & 2 & 6 & Turizm sektöründe çalışmaktadır. \\
\hline
\end{tabular}

8 kadın ile yarı yapılandırılmış görüşme formu kullanılarak derinlemesine mülakat tekniğgi aracılığı ile görüşülmüştür. Görüşme esnasında kolaylaştırıcı etmen olarak görüşmecilerin bilgisi ve izni dahilinde ses kayıt cihazı kullanılmıştır.

Daha fazla kişiyle görüşme yapılması planlanan bu çalışmada, kişi sayısının 8 ile sınırlandırılmasının sebebi, alanda görüşülen yüzler değişirken dile getirilen ifadelerin değişmediği gerçeği ile karşılaşılmasıdır.

\footnotetext{
1 Bu bölümde yazarın “Göç Süreciyle İş Hayatına Giren ‘Kadınlık’ Deneyimleri: Antalya Çolaklı Örneği” adlı Yüksek Lisans Tez çalışmasında yer alan verileri analizi tekrar kullanılmıştır.
} 


\subsection{Kadınların gözünden kadın ve kadınlık deneyimi}

Öncelikli olarak kadın ve kadınlık deneyimi deyince kadınların akıllarına ilk olarak neyin geldiği merak edilmiştir. Kadınların yapmış oldukları tanımlamalar ise kadınların söylemleri üzerinde etkisi olan toplumsal yapı dikkate alınarak analiz edilmeye çalışılmıştır.

Kadın anadır. Kadın herşeydir; ağaçtır, topraktır, çiçektir, böcektir, börtüdür, insandır. Kadın anadır. Yuvayı yapan kadındır. Kadın isterse adamı vezir de eder rezil de eder. Kadın herşeydir. Kadının tanımı yoktur. Gördüğün her yer kadındır.Çünkü doğuran herşey anadır. Ee kadın da doğurduğuna göre, her şey kadındır.” (G3)

Toplumsal rol ve kalıp yargıların örneklerinden biri olan ve kadınlık durumunun "doğası" ile özdeşleştirilen, ataerkil sistemin üzerine giydiği "fedakar bir k1lıf” olarak "annelik" olgusu, kadınlık durumunun yegane var oluş amacının anne olma pratiği üzerine inşa edildiği denetimli bir kuruluşa işaret etmektedir (Bal, 2014: 61). Bu bağlamda G3 de 'kadın' olmayı toplumun kadına yüklemiş olduğu bazı roller çerçevesinde ifade etmektedir. 'Kadın herşeydir' derken kadını 'yüceltmekte' ve bu yüceliği, özünde kadının doğurgan yani anne olmasına bağlamaktadır.

Ne gelir ne bilem ben. ne gelir bilmiyom ki. ee kadın ev hanımı. anlatayım başka? Eviyle ilgilenir. Yemeğini pişirir evinin işini tutar. Süpürgesini yapar ne diyeyim çamaşırını yıkar asar. Evinin temizliği ile uğraşır (G4).

Kadın dediğim zaman ilk aklıma gelen ne biliyo musun her işin kadının üstünde olduğu aklıma geliyo benim . Sorumluluğun çoğunun kadının üstünde olduğu geliyo aklıma benim (G8).

Kadın deyince 111... Evin geçimi, yuvayı dişi kuş kurar derler ya o gibi, evi çevirmek, çor çocukla ilgilenmek. Başka ne bileyim? kadın erkek eşitliği...(G2).

Görüşme yapılan kadınlar, 'kadın’ kavramının içini ataerkil bir toplumun dayatmış olduğu roller çerçevesinde doldururlarken 'kadınlık deneyimini', toplumsal cinsiyet eksenli rol ve görevler bağlamında "gündelik pratikleri” üzerinden tanımlamışlardır.

Kadınlık deneyimi 111 bilemedim, ne dicem ne bilem ben. Kadın her işi yapar ablam, ev işi de yapar bahçe işi de yapar, kadın her işi yapar. Erkek de yapar kadın da yapar. Kadın yapar yuvayı asıl ama de mi? ... ( biraz düşündü)Öyle canım kadın yapar erkek ne kadar yapsa da olmaz kadın yapar asıl. Ya tabi beraber olur da her şeyi birikleyen kadın olur bence öyle (G4).

Ne gelebilir 11 nasıl anlatayım yani kadın dediğim zaman teyzem ne bileyim yani her şeyi yapan, her şeyi çözen yani nasıl anlatayım nasıl anlatacamı da bilemedim şu an. Ya ne bileyim kadın... Deneyim... Hiç de aklıma gelmedi bişey (biraz düşündükten sonra) 111 ev işi ve de önemlisi annelik görevi, çocukların sorumluluğu. Hepsi annede yani fazlası. Ondan sonra dişta da öyle içte de öyle evde de öyle teyzem yani (G8). 
Anne olmak, evimi geçindirmek onu düzenlemek, evimin içine dışına bakmak, alışveriş yapmak, yemek yapmak gibi şeyler (G7).

İlk olarak annelik geliyor aklıma. Kadınlık deneyimi ilk annelikle başlıyor (G6).

Gündelik pratiklere ek olarak görüşme yapılan kadınların hepsi kadınlık deneyimleri kavramının içini annelik kavramıyla doldurmuşlardır. Bu açıdan bakınca annelik kavramı da başlı başına bir pratik olarak karşımıza çıkmaktadır. Kadın kimliğinin algılanışında çocuk sahibi olmanın önemli olduğu toplumsal yapıda kadınlar kendilerini annelik üzerinden tanımlayan refleksler gelişebilmekte ve hatta anneliği çoğu kez yüceltebilmektedirler.

Kadınlık deneyimi deyince dünyanın en zor mesleği çocuk yetiştirmek. Dünyanın en zor mesleği. Ama adam gibi adam, ana olmaktır en zor mesleği. Her insan ana olamaz. Her insan doğurur ama anne olmaz.Anne olmak bir evladın uyurken sağından soluna dönerken aldığı nefesi hissetmek demektir. Biliyo musun anne olmak öyle bir şeydir. Benim çocuklarım yan odadan uyurken ben yatakta döndüklerini öbür tarafta hissederdim, duyardım onu (G3.)

Salt biyolojik tanımlamanın ötesinde kültürel bağlamda tanımlanarak bazı kutsal değer atfedilen annelik genellikle duygularla ilişkilendirilerek kurgulanmakta ve özcü bakış açısına göre bu durum 'doğal' olarak kabul edilmektedir. Annelik içgüdüsü miti üzerinden tüm kadınların anne olmayı istediği algısı yaratılmaktadır (Sever, 2015: 73-74). Dolayısıyla doğuştan bireye içkin olmayan sadece toplumsallaşma süreciyle birlikte cinsiyetlere özgü normal nitelikler olarak gelenekselleşmiş, kadınlık ve erkeklik durumuna "uygun görülen” davranışların kronikleşmiş durumu olarak tanımlanabilecek kalıp yargılar karşımıza çıkmaktadır. Bu noktada annelik durumuna da kadının doğurganlık potansiyelinden hareketle merhamet, fedakarlık, güven, sadakat, koruma ve adanmışlık gibi pek çok toplumsal cinsiyete ilişkin rol ve kalıp yargılar atfedilmekte ve kadının anne olması yüceltilmektedir (Bal, 2014: 63-64).

Görüşülen G3 de anneliği yüceltmektedir. Yüceltirken de "adam gibi adam, ana olmak” şeklinde dile getirmiş olduğu söylemle cinsiyetçi bir dil kullanmakta ve "farkında olmadan" dil bağlamında cinsiyetçi pratikleri devam ettirmektedir. Çünkü içinde bulunmuş olduğumuz toplumda 'adam' olmak demek cinsiyetin erkeğini temsil etmekten ziyade “iyi, dürüst, güvenilir vd. gibi” kavramları da temsil etmektedir. Dolayısıyla içinde bulunmuş olduğumuz toplumda var olan cinsiyetçi pratikler kullanmış olduğumuz dil ile birlikte yeniden ve sürekli olarak üretilmektedir.

Literatürde de daha önce üzerinde durulduğu gibi bireyleri içinde bulundukları kültürle ilişkisini anlamada dil önemli bir yere sahiptir. Bu anlamda feminizmin en önemli tespitlerinden biri ise kadınların erkekler tarafından yaratılmış olan bir dilin içinde yaşıyor olduğu gerçeğidir. 


\subsection{Kadınların değişen ve değişmeyen deneyimleri}

Kadınların değişen/değişmeyen deneyimlerine görüşmeler bağlamında değinmek gerekirse;

Köyde yaşamakla Antalya'da yaşamak bir değil. Yani mesela köyde sabah erkenden kalkıyosun, tarlada takkada uğraşıyosun yorgun geliyosun amma burda gidiyosun sekiz saat çalışıyorun geliyosun. Saat beşten sonra rahatsın. Yani o avantaji var. Şu anda otelde çalışıyorum. Burda sabah yedide falan kalkıyon işime gidiyom. Saat beşte işi bırakıyosun eve geliyosun en azından beşten sonra denizine, çarşına gitmek istiyosan gidiyosun (G8).

Görüşme yapılan kadınların geneli göç etmiş oldukları bölgenin turizmle iç içe olmasından dolayı turizmde hizmet sektöründe çalışmaya başlamışlardır. Dolayısıyla bu durum kamusal alanda farklı pratikleri deneyimlemelerine neden olmuştur.

Turizimdeki çalışmak stresliymiş. Üstlerinle, yöneticiyle çalışmak insanların kaprisini çekmek çok zor... Başka bi işe de girmeyi düşünmedim. Yapcak bişey yok ki başka. Ordan buraya gelen turizm için geliyor (G5).

Beşeri anlamda daha az sermayeye sahip olan kırsal alandan kente göç eden bireylerin çoğunluğu daha düşük gelirli sektörlerde iş bulabilmektedirler. Söz konusu göçmen kadın olduğunda ise; kırsal alanda ücretsiz aile işçisi olarak kadın, kente geldiği zaman "potansiyel vasıfsız işgücü” olarak görülmektedir. Bu sebepten ötürü çalıştı̆̆1 işten memnun olmayan bazı kadınlar yapabilecekleri başka bir iş olmadığını düşündüklerinden mevcut işlerinde çalışmaya devam etmektedirler.

Yaylada genellikle ücretsiz aile işçisi olarak çalışmış olan görüşülen kadınlar göç ettikten sonra ücretli bir işte çalışmaya başlamış ve bu durum kadınların değişen deneyimleri noktasında etkili olmuştur. Ekonomik anlamda 'kendi' paralarını kazanmaya başlayan kadınlar, değişen deneyimleri noktasında bu ayrıntıya dikkat çekmişlerdir.

Oradakiler (Gedikli’yi kastediyor) günlük kazanıp günlük şey yaptığı için programını ya da harcamanı ona göre ayarlıyosun ama burda belli bi aylığı alacağın için programı ona göre yapıyosun. Orda yarın kazanamayacam endişesi varya mutlaka bi kenara bişey koymak zorundasın. Ama burda yarın da çalışıım, çalışacam maaşımı öbür ay da alacam şeyiyle burdaki şey daha farklı oluyo (G3).

...Söz sahibi olmanı istediğin şeyi alabilmeni sağlıyo...(G6).

Her ne kadar kadının çalışması emek sömürüsü üzerine temellenmiş olsa da yoksullukla baş edebilme açısından, aile gelirine kadın cephesinden bir katkı olduğu için önemli bir işlevi yerine getirmektedir. Dolayısıyla bu durum, ataerkil aile ilişkilerinde -kadının söz sahibi olması 
gibi- bazı dönüşümleri beraberinde getirebilmektedir (Buz, 2009:47). Zira alan araştırmasında görüşülen kadınların pek çoğu ücertli bir işte çalışmanın ekonomik anlamda kendilerine güç verdiğinden ve hane içinde söz sahibi olmaya başladıklarından bahsetmişlerdir. Bu açıdan bakıldığında kadının ücretli bir işte çalışması, ev içi geleneksel rol ve görevler bağlamında kadınların deneyimlemiş oldukları gündelik pratikleri değiştirme gücünü içinde barındırmaktadır.

Muhasebe işlerine eşim bakar. Canım istediğinde harcarım ama tabi parayı alırken sorar ne yapacaksın diye, ben de söylerim aldıklarımı (G2).

Kazandığımız paranın kontrolü eşimde ama ben istediğim gibi harcarım ve hiç sıkıntı olmamıştır bu güne kadar. Bulduğumda harcadım hiç affetmem (G3).

Görüşme yapılan kadınların çoğunluğu her ne kadar maaşlarını kontrol etme ve maaşları üzerinde söz sahibi olma anlamında "ikinci planda" olsalar da, kadınların kendileri tarafından ücretli bir işte çalışıyor olmaları ekonomik anlamda özgür olmaları ile eş değer olarak algilanmaktadir.

Ayrıca görüşülen kadınlar, değişen/değişmeyen kadınlık deneyimleri noktasında ücretli iş gücüne katılmalarıyla birlikte kadının ve erkeğin ev içinde üstlenmiş oldukları görev ve sorumluluklara değinmişlerdir.

Köyde de ev işini ben yapıyodum burda da ben yapıyom ama burda bi düzen var. Köyde bana göre öyle değil. Yayladayken malla melenle uğraşıyodum. Antalya'ya geldim o tür uğraştığın bişey yok. Yayladayken eve gelince tarladan takkadan, evin içine girsen mal var melen var, tavuk var, köpek var hesabı oluyo köye vardın mı. Yani anam anam gadın anam bana göre. Burda saat beşten sonra eve geldin mi en azından bi gezmeye gidebiliyosun malın melenin yok. Arkana çekecek bişeyin yok yani ya da geliyosun yatıp dinlenebiliyosun o şansın var ama orda öyle yok bana göre (G8).

...birimiz yemeği yapar, birimiz çayı demler gibi ya da sofrayı kurar gibi. Ama yaylada mesela erkek oturuyo sofra önüne geliyor sofra kalkıyo çay önüne geliyo... (G5).

Alan araştırması süresince karşımıza iki farklı fotoğraf çıkmaktadır. İlk fotoğraf; ücretli işgücüne katılan kadınların eşlerinin, ev işlerine "ortak olmak" anlamından ziyade "yardım etmek" anlamında dahil oldukları ve kadınların kırsal alanda ev işinde aldıkları görev ve sorumlulukların kente gelip ücretli iş gücüne katıldıktan sonra hafiflediği bir görüntüyü “temsil” etmektedir.

Yayladayken de aynıdı. Tarlada çalışırdık evde gelir yemek falan yapardık. Yine aynı bütün işleri ben yapıyorum. Sürekli kadın çalışır yani bizde. Erkek oturur şu getir bunu getir, şunu yapcaksın, bunu yapcaksin der." (G7)

Ev işlerindeki deneyimim değişmedi, yine ben yapıyom, aynı şeyler hiç birşey değişmedi." (G1) 
İkinci fotoğraf ise hem ücretli işte çalışıp hem de geleneksel 'kadınlık' görevlerini de yerine getiren kadınların aile içi sorumluluklarının arttığı bir görüntüyü “temsil etmektedir”.

Her iki fotoğrafın ortak noktası ise temelinde ataerkil pratiklerin olduğu gerçeğidir. Zira ev işlerine "yardım etmek" anlamında erkeğin dahil olması özünde ev işlerinin kadına ait olduğu düşüncesini beslemektedir.

Ayrıca görüşülen kadınlar, kent yaşamı bağlamında gündelik pratikler anlamında farklı deneyimleri yaşadıklarından da söz etmişlerdir.

Gençlik takımı pantolondur, askılıdır. Yine burda giyinebildiği gibi giyinebiliyor. Biz de giysek bişey olmaz yani canımız istese giyinebilirsin. Ama o köye gittiğinde şalvar giyiyosun başına örtü yapıyosun. Ama yine de giysen açık dursan da giyilebiliyor artık. Halk anormal karşılamıyor. Köyde de giyebilirsin aynı kıyafeti burda da. Ama ben gittiğimde şalvarı tercih ederim. Daha rahat. Özlüyorsun (G2).

Köydeki giyinme tarzınla burdaki değişiyo. Köyde sürekli pantolon giyemezsin sürekli şalvarla dolaşırsın. Ama burda istediğin yere pantolon da gidebiliyosun etekle de gidebiliyosun eşofmanla da gidebiliyosun. Modaya uyuyorsun yani (G5).

Giyim tarzım değişti eğer deneyime girerse bilemedim şuan... Yaylada şalvarla tişörtle, çolaklıda ip askılı şort (G1).

Orda sürekli şalvar giyerdik. Burada yerine göre etek yerine göre pantolon yerine göre ask1lı falan giyebiliyosun. Ne bilem denizde şort falan giyiliyo yani (G7).

Kentler sadece coğrafyada bir yer değildir aynı zamanda bir yaşam biçimidir de dolayısıyla kırdan kente yapılan göç, sonrasında bireylerin gündelik yaşayışlarında bazı farklılıkların meydana gelmesine ve bu bağlamda deneyimlerinin değişmesine neden olmaktadır (Wirth, 1935: 22; akt. Kaypak, 2014: 347). Örneğin; şehir yaşamı, hem bir tarza sahip olma bilincini hem de bireysel seçimleri yansıtabilecek bir alan içinde tüketme gereksinimini ortaya çıkarmakta ya da artırmaktadır. Dolayısıyla şehirdeki birey, daha çok bir kimlik duygusu yaratabilmek amacıyla tüketmektedir. Bu bağlamda kendisini diğer bireylerden farklı kılabilmek için bireyin kullandığı giyim tarzının aynı zamanda diğer bireyler tarafından da anlaşılıp yorumlanabilmesi gerekmektedir. O halde bir birey, kendisini ancak diğerleri ile ortak birtakım kültürel sembolleri paylaşabildiği ölçüde farklı kılabilmektedir (Bocock, 2005: 27). Dolayısıyla kırsal alanda genellikle şalvar giydiklerini dile getiren görüşme yapılan kadınlar kente geldikten sonra -kentte bulundukları farklı mekanlar bağlamında- giyim tarzlarında farklılıklar yaşamışlardır.

Yaylada insanlar Çolaklı'dan daha özgür yaşıyor. Nasıl mesela insanlar saat 9, 10’a kadar günlük şey yapıyo, öğleyin dinlenme saati var ya üç-beş kadın komuşusun zaten bi araya toplanıyosun 
sohbet ediyosun. İşin varsa ben şu işi yapacam bana yardım edin diyosun. Orda zaman sınırı yok ya da bunu bugün yapmak zorundayım diye kavram yok. Burda zaman sınırın var mesela işe giden kadın sabah sekiz akşam beş bu işi yetiştirmek zorundayım diyerek yapıyo orda öyle bişey yok. Daha özgür, insanlar daha özgür. insanlar istediği saatte yatıp uyuyo istediği saatte geziyo...”(G3).

Bu bağlamda kentler sosyal, kültürel, ekonomik, hukuksal ve demografik özellikleri bakımından kırsal alanlardan farkl1, toplumsal farklılaşma ve hareketliliğin görüldüğü yerleşmelerdir. Bu hareketlilik ise insanları kıra kıyasla daha zaman odaklı yaşamaya itmektedir. Dolayısıyla kentsel yaşamın getirmiş olduğu yaşam biçimi bu anlamda cinsiyet farkı gözetmeksizin bireylerin yaşam biçimlerinde farklılıklara ve bu faklılıklar ise farklı deneyimlere yol açabilmektedir. Kırdan kente göç süreciyle her ne kadar bireyler gündelik yaşam pratikleri anlamında farklı deneyimleri yaşamış olsalar da söz konusu kadınlar olduğu zaman toplumsal cinsiyet algısının dayatmış olduğu rol ve görevler bağlamında değişmeyen deneyimlerin varlığı da söz konusudur.

\section{Sonuç ve Değerlendirme}

$\mathrm{Bu}$ çalışma ile nesneleşen/şeyleşen deneyim kavramı bağlamında iç göç süreciyle iş hayatına giren kadınların 'kadınlık' deneyimleri, hermeneuitik anlama çabası ile birlikte anlaşılıp yorumlanmaya çalışılmıştır. Pek çok göç çalışmasında göçün nedenleri ve sonuçları itibariyle görünmez kitleyi oluşturan kadınların bu çalışmada görünür kılınması hedeflenmiştir. $\mathrm{Bu}$ yapılırken de genellemeler yapmaktan kaçınılarak alandaki kadınların tikellikleri göz önünde bulundurulmuştur. Böyle yapılarak çalışmanın sonuçlarının diğer kadınlara genellenmesi de bir noktada engellenmeye çalışılmıştır. Zira bu çalışmada elde edilen bulguların diğer kadınlara genellenmesi onların bilgilerini ürettiği noktada bazı kadınların deneyimlerinin üstünü örtecektir.

Bu noktada alan verilerini kısaca değerlendirmek gerekirse;

Görüşme yapılan kadınlar, 'kadın' ve 'erkek’i biyolojik cinsiyet bağlamında değil toplumsal cinsiyet bağlamında tanımlamışlardır. Dolayısıyla bireylerin akıllarında oluşan kadın ve erkek algısının, sosyalizasyona uğramış oldukları toplumun kadına ve erkeğe yüklemiş olduğu rol ve görevler bağlamında oluştuğunu söylemek mümkündür.

Bu bağlamda görüşme yapılan kadınlar, kadını; anne, çocuğuyla ilgilenen, yemeği yapan, eviyle ilgilenip temizliğini yapan ,"yuvayı dişi kuş kurar” mantığıyla evi çeviren bir birey olarak tanımlarken; erkeği ise öncelikli olarak baba, evin direği, evin reisi, güç ve otoritenin simgesi, evini geçindiren şeklinde tanımlamışlardır. Ayrıca görüşme yapılan kadınlar bağlamında ifade etmek gerekirse; kadınlar iş hayatına girmiş olsalar dahi kendilerini tanımlarken kamusal alan üzerinden değil de özel alan üzerinden ifade etmişlerdir. 
Özel alandaki rol ve görevlerin ise annelik dolayımıyla da şekillendiği gerçeği alan araştırmasında karşılaşılan en önemli unsurlardan biridir. Çünkü annelik ataerkil bir toplumun değerleri bağlamında belirlenen aile ilişkilerinde, kadınların toplumsal cinsiyet rollerinin önemli bir parçası haline gelmektedir. Bu bakımdan annelik kavramı, ona yüklenen anlamlar bağlamında, rol görevlerin cinsiyetlendirilmesine yol açan bir kavram olarak alanda karşımıza çıkarken aynı zamanda kadınların kendilerini annelik üzerinden var ettikleri bir kavram olarak da ön plana çıkmaktadır. Çünkü toplumun anneliğe atfetmiş olduğu değerler cinsiyetçi pratikleri beslerken öte yandan da anneliği yüceltmektedir. Bu yücelik toplumsal anlamda anneliğe belli bir statü atfetmekte ve bu statü üzerinden bazı kadınlar kendilerini var ederek tanımlamaktadırlar.

'Kadınlık deneyimi' kavramı söz konusu olduğu zaman; kadınlar, 'kadınlık deneyimi' kavramının içini de -anne olmanın yanı sıra- kadınlara toplumsal anlamda atfedilmiş olan geleneksel rol ve kalıplar bağlamında doldurmuşlardır. Dolayısıyla kadınlığın ve erkekliğin toplumsal cinsiyet ekseninde tanımladığı bir toplumda deneyimlerin de bu çerçevede şekillendiği gerçeği ile karşılaşılmıştır.

Görüşmeler sonucunda; kadınların toplumsal cinsiyet kalıpları bağlamında tanımlamış oldukları 'kadın' tanımı bizleri yine toplumsal cinsiyet bağlamında deneyimlenen 'gündelik yaşam pratikleri’ üzerinden deneyim kavramına götürmüştür. Deneyimin değişkenlik göstermesi ya da statik olarak kalması ise yine bu çerçevede kendini göstermiştir. Ancak kadınlar, gündelik hayatlarında yapmış oldukları faaliyetlerin tümünü 'kadınlık deneyimi' kavramının içini doldurmak için kullanmazlarken, değișen deneyim noktasında gündelik hayatlarındaki pratikler üzerinden de cevap vermişlerdir. Bu bağlamda salt deneyim kavramı bizi daha çok 'gündelik pratiklere' götürürken, 'kadınlık deneyimi' kavramı ise toplumsal cinsiyet bağlamında deneyimlenen pratiklere götürmektedir. Ancak son kertede bakıldığı zaman 'gündelik pratikleri', toplumsal cinsiyetten ayrı düşünmek imkansızdır. Çünkü bireylerin gündelik pratikleri bu eksen çerçevesinde şekillenmektedir. Bu bağlamda yapılan alan araştırması bizi 'nesneleşen/ şeyleşen deneyim' kavramına götürmüştür.

Nesneleşen/Şeyleşen deneyim kavramını açıklamak gerekirse; Cinsiyetlerin toplumsal cinsiyet ekseninde tanımlanarak nesneleştirilmesi/şeyleştirilmesi bağlamında bireylerin "kadınlık ve erkeklik” deneyimlerinin içini de bu eksende doldurmasıdır. Yani şeyleştirilen/nesneleştirilen cinsiyetlerin, deneyimlerinin de şeyleşmesi/ nesneleşmesidir.

$\mathrm{Bu}$ bağlamda görüşme yapılan kadınlar geleneksel rol ve görevler bağlamında kadını tanımlayarak nesneleştirmişler ve nesneleştirdikleri 'kadın' tanımı çerçevesinde 'kadınlık 
deneyiminin' içini doldurmuşlardır. Dolayısıyla bu durum bizi deneyimin de nesneleştiği gerçeği ile karşı karşıya getirmiştir.

Görüşme yapılan kadınların 'kadınlık deneyimi’ kavramının içini doldururlarken dikkate almadıkları gündelik pratikler bağlamındaki deneyimleri ise bazı değişikliklere uğrarken; kadınların 'nesneleşen/şeyleşen deneyimleri' ise radikal bir dönüşüme uğramamıştır. Örneğin; gerek 'kadın' gerek ise 'kadınlık deneyimi' tanımlamaları yapılırken kullanılan "annelik" kavramından kadınlık deneyiminin değiştiği noktada hiç bahsedilmemiştir. Görüşülenler kadınların içini “ev hanımı, evi çekip çeviren, çocuğuyla ilgilenen, yuvayı yapan” şeklinde tanımladıkları deneyimleri noktasında ise her hangi bir radikal bir değișimle değil yalnızca belli başlı dönüşümlerle karşılaşılmıştır.

Kadınların ücretsiz aile işcisiyken ücretli iş gücüne katılmaları bağlamında, ev içinde üstlendikleri rol ve görevler anlamında, değişen/değişmeyen kadınlık deneyimleri noktasında ise; iki farklı durumdan bahsetmek mümkündür; ilki hem ücretli işte çalışıp hem de geleneksel 'kadınlık' görevlerini de yerine getiren kadınların aile içi sorumluluklarının arttığıdır. İkincisi ise ücretli iş gücüne katılan kadınların eşlerinin, ev işlerine "yardım etmek" anlamında dahil olduğu ve kadına yüklenen aile içi sorumluluğun azaldığıdır.

Ancak geniş perspektiften bakıldığı zaman her iki durum da özünde ataerkil kodları taşımaktadır. Her iki durumda da ev işleri kadının görevi olarak görülmektedir. Erkeğin ev işlerine dahil olması da bu eksende gerçekleşmektedir. Çünkü erkek eşine yardım eden bir pozisyonda konumlanmakta ve bu durum çoğu zaman yetenekle meşrulaştırılmaktadır.

Ayrıca geldikleri bölgede ücretsiz aile işçisi olarak çalışan kadınlar, tarımsal üretimin yapılmadığı kentlerde kamusal alanda ücretli işçi olarak çalışarak ekonomik anlamda kendi paralarının kazanmaya başlamışlardır. Kadınların ekonomik anlamda kendi paralarını kazanmaları söz konusu olduğu zaman göç etme sürecinin kadınları özgürleştirdiğine dair literatürde düşünceler mevcut olsa da alan araştırması bu durumun aksi yönündedir. Kadınlar her ne kadar iş alanlarında var olarak ekonomik anlamda belli bir gelire sahip olsalar da "paranın kontrolü" nün eşlerinde olması sebebiyle kadınlar için tam anlamıyla ekonomik özgürlükten bahsetmek mümkün olmamaktadir.

Kırdan farklı olarak toplumsal farklılaşma, mesleki uzmanlaşma ve hareketliliğin görüldüğü kentler insanları kıra kıyasla daha zaman odaklı yaşamaya itmiştir. Yalnızca bir coğrafya değil aynı zamanda bir yaşam biçimi olan kentin sosyal, kültürel, ekonomik, demografik özellikler başta olmak üzere pek çok bakımından kırsal bölgelerden farklılık göstermesi bireylerin 
"gündelik yaşamlarında" farklı pratikleri deneyimlemelerine neden olurken; kadınların toplumsal cinsiyet bağlamında içini doldurdukları deneyimlerinde radikal bir farklılıkla karşılaşılmamıştır.

\section{Summary}

In many studies on migration, a male-dominated perspective which keeps women subordinate is enforced. It is overlooked by some migration studies that each individual may be affected differently from migration processes in terms of one's gender, socio-economic status, and cultural characteristics, ethnic and religious identity.

Migrant individuals should be considered as actors when the phenomenon of migration is examined. Based on this reality, this study discusses internal migration movement from rural to urban areas in the context of the feminine experience of women who enter the labor force through migration The concept of experience emphasizes some women's experiences at the cost of making the rest as secondary, which establishes a relationship of power Women's experiences regarded not as pure knowledge are analyzed through a hermeneutic and post-modern feminist understanding which emphasizes the importance of cultural factors. In this qualitative study in-depth interviews were conducted with eight women.

Participants of the research defined women and men within the context of gender not in terms of biology. They consider the woman as an individual who takes care of the children, cooks, cleans and takes care of the house while they defined the man as the father, the head of his family, the symbol of power and authority.Women's entering the labor force does not put an end for women to be identified with private sphere. When the concept of feminine experience is concerned; it is seen that women have adopted it in the context of traditional roles and patterns they have been ascribed to.

It is clear that experiences are also constructed in a society where femininities and masculinities are determined with reference to gender.

As a result of the research, it can be stated that participants have defined and objectified women in the context of traditional roles and tasks and they constructed feminine experience via those definitions. Therefore, this situation leads to the fact that experience is also objectified.

Two different situations with regards to domestic labor arise from women's entering the labor force. The first one implies to a situation where women spend more time on unpaid care work and the other one leads to a condition where their husbands are involved in unpaid care work as "helping husbands". 
Furthermore, women who were unpaid family workers in the cities they came from, start to earn their own money as paid workers in the public space upon migrating to cities. This process of migration is thought to empower women economically yet; the results of the field show that women do not become financially independent as men still have control over money.

Participants' responses with regards to how they experience change are shaped through their everyday practices. They do not include all of their everyday life practices to construct the feminine experience, though. Some experiences which participants do not take into consideration while constructing the femininity experience in their narratives are changed. However, their experiences which are objectified and reified have not changed dramatically.

Migrating from rural areas to cities results in the fact that women start to become more time-oriented as social differentiation, professional specialization, and mobility occur in cities more than in rural areas.

\section{Yazar Notu:}

Bu çalışma, Dr. Öğretim Üyesi Savaş Çağlayan danışmanlığında Asiye Kemik tarafından Muğla Sıtkı Koçman Üniversitesi Sosyal Bilimler Enstitüsü Sosyoloji Anabilim Dalında hazırlanan “Göç Süreciye İş Hayatına Giren Kadınların 'Kadınlık’ Deneyimleri: Antalya Çolaklı Örneği” adlı tezden üretilmiştir.

\section{Kaynakça}

Abadan Unat, N., (1991). "Dış Göç Akımının Türk Kadınının Özgürleşme ve Sözde Özgürleşme Sürecine Etkisi”, Aile Yazıları 2 Kültürel Değerler ve Sosyal Değişme, Ankara, T. C. Başbakanlık Aile Kurumu Bilim Serisi 5/2.

Aşkın, Z., Çellik, H., (2015). “Hermeneutiğin Ontolojik Temellendirilişi: Heidegger ve Gadamer”, Beytulhikme An International Journal of Philosophy, Volume:5 Issue 2.

Bal, S., (2014). 'Reklamların Eskimeyen Yüzü 'Muhteşem Annelik’ Anneler Günü Reklamları Örneği”, Başkent Üniveristesi, Halkla İlişkiler Bölümü, İlef Dergisil(2)/Sonbahar (59-85)

Başel, H., (2006). “İç Göçün Sonuçları Ve İşgücüne Etkileri”, Cumhuriyet Üniversitesi, İ.İ.B.F., Çalışma Ekonomisi ve Endüstri İlişkileri Bölümü. Sosyal Siyaset Konferansları Dergisi, Sayı 51.

Bocock, R., (2005). Tüketim. (İ. Kutluk, Çev.) Ankara: Dost Kitapevi.

Bora, A., (2005). Kadınların Sınıfi Ücretli Ev Emeği Ve Kadın Öznelliğinin İnşası, İstanbul: İletişim Yayınları. 
Buz, S., (2009). “Göç ve Kentleşme Sürecinde Kadınların ‘Görünürlüğü’’’. Hacettepe Üniversitesi, İktisadi ve İdari Bilimler Fakültesi, Sosyal Hizmet Bölümü. Aile ve Toplum Dergisi, Cilt 5, Sayl 17, (Nisan-May1s-Haziran 2009).

Coşkun, O., (2008), “ İç Göçler Açısından Erzurum İlinin Analizi”, Doğu Coğrafya Dergisi Cilt 13, Sayı 20, ss 239-266

Çelik, H., Ekşi, H., (2008). "Söylem Analizi”, Marmara Üniversitesi Eğitim Bilimleri Dergisi, İstanbul: Sayı 27. Cilt I, s. 99-117.

Erman, T. (1998). “Kadınların Bakış Açısından Köyden Kente Göç ve Kentteki Yaşam” 75 Yılda Kadınlar ve Erkekler Bilanço 98, İstanbul: Türkiye İş Bankası Kültür Yayınları ve Tarih Vakfı Ortak Yayını.

Gündüz, M., Yetim, N., (1996). “Terör ve Göç”, II. Ulusal Sosyoloji Kongresi, (Toplum ve Göç), Ankara: Sosyoloji Derneği.

Gür, T., H., Ural, E., (2004). “ Türkiye'de Kentlere Göçün Nedenleri”, Hacettepe Üniversitesi İktisadi ve İdari Bilimler Fakültesi Dergisi, Ankara: Cilt 22, Sayı 1, ss23-38.

Irzık, S., Parla, J., (2004). Kadınlar Dile Düşünce, İstanbul: İletişim Yayınları. İçduygu, A., Sirkeci, İ., Aydıngün, İ., (1998). “Türkiye’de İç Göç ve İç Göçün İşçi Hareketine Etkisi” içinde Türkiye' de Iç Göç, İstanbul: Tarih Vakfı Yayınları.

İlkkaracan, İ., İlkkaracan, P., (1999). “1990’lar Türkiye’sinde Kadın ve Göç”, 75 Yılda Köylerden Şehirlere, İstanbul: Tarih Vakfı Yayınları.

Kaya, E., (2007). Kentleşme ve Kentlileşme. İstanbul: Okutan Yayınc1lık.

Kaypak, Ş., (2014). “Toplumsal Cinsiyet Bakış Açısından Kente Bakmak”, Niğde Üniversitesi İ̈BF Dergisi, Cilt 7, Sayı 1, s. 344-357.

Keleş, R., (1998). Kent Bilim Terimleri Sözlüğü, Ankara: İmge Kitabevi.

Kocaman, T., (2008). Türkiye 'de Iç̧ Göçler ve Göç Edenlerin Nitelikleri (1965-2000), DTP, Sosyal Sektörler ve Koordinasyon Genel Müdürlügüü.

Korkmaz, A. ve Korkut, G., (2012). "Türkiye’de Kadının İşgücüne Katılımının Belirleyicileri”, Süleyman Demirel Üniversitesi İktisadi ve İdari Bilimler Fakültesi Dergisi, C.17, S.2, s.41-65.

Kuyucuoğlu, İ., (2015). "Sosyolojinin Kuruluşunu Etkileyen Düşünce Akımları ve Klasik Sosyolojide Yöntem Tartışmaları”, Uluslararası Sosyal Araştırmalar Dergisi, Cilt:8, Sayı:36. 
Metin, Ş., (2011). “Kayıt Dışı İstihdam Ve Esnek Üretim Sürecinde Kadın Emeğinin Durumu: Türkiye'de Ev-Eksenli Çalışma” Uzmanlık Tezi, T.C. Başbakanlık Kadının Statüsü Genel Müdürlüğü.

Oktik, N., (1996). "Köyün İticiliği-Kentin Çekiciliğii”, II. Sosyoloji Kongresi (Toplum ve Göç), Mersin: Sosyoloji Derneği.

Onat, Ü., (1993). Gecekondu Kadının Kente Özgü Düşünce ve Davranışlar Geliştirme Süreci, Kadın ve Sosyal Hizmetler Müsteşarlığı, KSHM; yayın no.73, Ankara: Kılıçaslan Matbaacılık Sanayi ve Tic.Ltd. Şti.

Öztan, E., (2016). “Feminist Araştırmalar ve Yöntem”. Toplumsal Cinsiyet Tartışmalarl (içinde) 269-287, Ed. Feryal Saygılıgil, Ankara: Dipnot Yayınları

Sever, M., (2015). “Kadınlık, annelik, gönüllü çocuksuzluk: Elisabeth Badinter'den Kadınlık mı Annelik mi?, Tina Miller'dan Annelik Duygusu: Mitler ve Deneyimler ve Corinne Maier'den No Kid Üzerinden Bir Karşılaştırmalı Okuma Çalışması”, Fe Dergi 7, (no.2 ,72-86). Yayınlayan: Ankara Üniversitesi KASAUM

Şeker, D. ve Uçan, G., (2016). “Göç Sürecinde Kadın”, Celal Bayar Üniversitesi Sosyal bilimler Dergisi Cilt:14, Sayl:1 Mart

Taş, B., (2008). “Catherine Breillat Sineması'nda Kadın Cinselliği ve Beden Algısı”, Yüksek Lisans Tezi, Ankara Üniversitesi Sosyal Bilimler Enstitüsü, Ankara.

Taşdelen, V., (2008), Hermeneutiğin Evrimi “Kesitler”, Ankara: Hece Yayınları

Tümen Bilgen, C., (2005). "Yaşam Öyküleri Üzerinden Kadınlık Deneyimleri”, Yüksek Lisans Tezi, Ankara Üniversitesi Sosyal Bilimler Enstitüsü, Ankara.

Yüksel, M., (2001). "Feminist Hukuk Kuramı ve Feminist Düşünce”, Yayınlanmamış Doktora Tezi, Marmara Üniversitesi Sosyal Bilimler Enstitüsü, İstanbul. 